ON THE ALTERNATIVE PROPOSALS SUBMITTED TO THE INTERNATIONAL COMMISSION ON ZOOLOGICAL NOMENCLATURE IN REGARD TO THE TRIVIAL NAME TO BE USED FOR COMMON GARTER SNAKE OF THE EASTERN UNITED STATES

\author{
By ARNOLD B. GRUBMAN \\ (University of Florida, School of Arts and Sciences, Department of Biology, \\ Gainesville, Florida, U.S.A.)
}

(Commission's reference Z.N.(S.)433)

(Letter dated 12th March 1952)

Of the two solutions proposed regarding the nomenclature of the common garter snake and the ribbonsnake, I prefer that of Dowling to that of Schmidt and Conant.

If there were a possibility of using sirtalis for the common garter snake and sauritus for the ribbonsnake from now on, I would think that would be most desirable. I am not sure however whether this could be accomplished within the structure of the Code.

Both of these snakes are well known in semi-popular literature and the names have been used as I have indicated. Either of the two formal proposals is going to result in continued confusion for a while.

\title{
ON THE SCOPE OF THE PLENARY POWERS BESTOWED UPON THE INTERNATIONAL COMMISSION ON ZOO. LOGICAL NOMENCLATURE BY THE INTERNATIONAL CONGRESS OF ZOOLOGY, WITH SPECIAL REFERENCE TO THE PROBLEM PRESENTED BY THE TRIVIAL NAME "SIRTALIS" LINNAEUS, 1758 (AS PUBLISHED IN THE COMBINATION “COLUBER SIRTALIS”) (CLASS REPTILIA)
}

\author{
By FRANCIS HEMMING, C.M.G., C.B.E. \\ (Secretary to the International Commission on Zoological Nomenclature)
}

(Commission's reference Z.N.(S.)433)

In the discussion which has taken place regarding the relative advantages of the proposals submitted (1) by Dr. Karl P. Schmidt and Mr. Roger Conant, and (2) by Dr. Herndon G. Dowling, for stabilising the trivial names to be applied to the Garter Snake and the Ribbon Snake respectively, reference has been made both by Professor Hobart M. Smith (in his letter of 23rd January 1952) and by Professor Arnold G. Grubman (in his letter of 12th March 1952) to doubts which they entertain as to whether the scope of the plenary powers granted to the International Commission on Zoological Nomenclature by the International Congress of Zoology is such as would permit the Commission, if it so desired, to approve the solution of the foregoing problem recommended by Dr. Schmidt and Mr. Conant.

2. In order that the issue of the settlement to be reached in regard to the trivial names to be used for the two snakes referred to above may not be obscured by misunderstandings regarding the scope of the Commission's plenary powers, it will be convenient here to note what is, in fact, the scope of those powers. For this purpose we may examine first the Resolution adopted at Monaco in 1913 under which those powers were originally conferred upon the Commission (see 1943, Ops. Decls. int. Comm. zool. Nomencl. $1: 37-40$ ) by the Ninth International Congress of Zoology, and, second, the decisions taken in Paris in 1948 by the Thirteenth International Congress of Zoology, when it incorporated the plenary powers provisions into the Règles (see 1950, Bull. zool. Nomencl. 4 : 55-56 (Paris Session, 3rd Meeting, Conclusion 7), 291-293 (Paris Session, 11th Meeting, Conclusion 10). 
3. The Plenary Powers Resolution of 1913 were granted to the Commission for application " to any given case where, in its [the Commission's] judgment, the strict application of the Règles will clearly result in greater confusion than uniformity ..." Thus, under this Resolution, the Commission was authorised to use the plenary powers then conferred upon it only when, in its judgment, certain conditions had clearly been complied with but that no limitation of any kind was placed upon the Commission as to the manner in which it should use its plenary powers or as to the Articles of the Règles which it might use those plenary powers to suspend in any case where it was satisfied that the overriding condition that " the strict application of the Règles would clearly lead to greater confusion than uniformity " had been complied with.

4. At its Third Meeting during its Paris Session the Commission drew up certain recommendations for changes in the text of the Plenary Powers Resolution but these recommendations were concerned only with mechanics and other procedural matters arising in connection with the use of the Plenary Powers (loc. cit. 4 : 55-56) and proposed no changes in the portion of the Resolution which actually conferred the Plenary Powers upon the Commission. At the same meeting, the Commission recommended that the Plenary Powers Resolution, amended as proposed, should be incorporated into the Règles (loc. cit. $4: 56$, Point (2)). These recommendations were later endorsed by the Section on Nomenclature (1950, Bull. zool. Nomencl. 5 : 5-13). At its Eleventh Meeting during the same Session the Commission agreed upon certain recommendations for the incorporation into the Règles of an Article prescribing the functions of the Commission; - the recommendations so adopted included a recommendation that the proposed new Article should prescribe that " the Commission possesses plenary powers to suspend, in whole or in part, any Article of the Règles, other than the present Article [i.e. other than the Article defining the functions of the Commission], as applied to the names in any book or to any individual name, where, in its opinion ... "(here follow the rules in regard to the use by the Commission of its plenary powers as agreed upon by the Ninth International Congress of Zoology at Monaco in 1913, as amended by the Paris Congress). This recommendation was endorsed by the Section on Nomenclature $(1950$, Bull. zool. Nomencl. 5 : 91-93). All the recommendations referred to above were later approved, with other recommendations, by the Thirteenth International Congress of Zoology in Plenary Session (1950, Bull. zool. Nomencl. 5 : 131).

5. We see therefore that the International Congress of Zoology has now explicitly authorised the International Commission to use its Plenary Powers to suspend the operation, in whole or in part, of any of the Articles of the Règles (other than the Article defining the functions of the Commission itself) in relation to any individual name, where, in its opinion, the strict application of the Règles would clearly result in greater confusion than uniformity.

6. The foregoing review of the scope of the Commission's plenary powers shows that it would be within the competence of the Commission to use its plenary powers for example, to suspend, in part, the provisions relating to type specimens in any individual case where it considered this necessary, in order to prevent greater confusion than uniformity from arising (as the result of the strict application of the normal provisions of the Règles). Subject to its being satisfied on this question, the Commission could therefore, in the individual case on which this problem has been raised, use its plenary powers to direct that any published description or figure or any individual specimen which it might so select, should represent, or, as the case might be, should be for the purposes of zoological nomenclature, the lectotype of, and therefore the sole standard for the interpretation of, the nominal species Coluber sirtalis Linnaeus, 1758.

7. So far therefore as its powers are concerned, the International Commission, when it comes to consider the applications submitted to it by Dr. Karl P. Schmidt, jointly with Mr. Roger Conant, and Dr. Herndon G. Dowling, will be free to approve or to reject, as it may think proper, either of the proposals so submitted. 


\section{$2 \mathrm{BHL}$ Biodiversity Heritage Library}

Hemming, Francis. 1952. "On the scope of the plenary powers bestowed upon the International Commission on Zoological Nomenclature by the International Congress of Zoology, with special reference to the problem presented by the trivial name sirtalis Linnaeus, 1758 (as published i." The Bulletin of zoological nomenclature 6, 217-218. https://doi.org/10.5962/bhl.part.16034.

View This Item Online: https://www.biodiversitylibrary.org/item/44304

DOI: https://doi.org/10.5962/bhl.part.16034

Permalink: https://www.biodiversitylibrary.org/partpdf/16034

\section{Holding Institution}

Natural History Museum Library, London

\section{Sponsored by}

Natural History Museum Library, London

\section{Copyright \& Reuse}

Copyright Status: In copyright. Digitized with the permission of the rights holder.

License: http://creativecommons.org/licenses/by-nc-sa/3.0/

Rights: https://biodiversitylibrary.org/permissions

This document was created from content at the Biodiversity Heritage Library, the world's largest open access digital library for biodiversity literature and archives. Visit BHL at https://www.biodiversitylibrary.org. 